\title{
The Kinetics of the Synthesis of Photopigments in Rhodopseudomonas spheroides
}

\author{
BY W. R. SISTROM \\ The Biological Laboratories, Harvard University, Cambridge 38, Massachusetts, U.S.A.
}

(Received 30 October 1961)

\section{SUMMARY}

The magnitude of self-shading in light-grown cultures of Rhodopseudomonas spheroides has been estimated. When a culture of $\boldsymbol{R}$. spheroides is transferred from bright light to dim light there is preferential synthesis of bacteriochlorophyll and carotenoid pigments relative to net protein synthesis. Protein turnover does not account for this.

The kinetics of the synthesis of bacteriochlorophyll relative to the incorporation of amino acids into protein have been estimated under a variety of conditions. On the basis of these findings a mechanism for the cellular control of pigment synthesis is presented.

\section{INTRODUCTION}

Experiments of Cohen-Bazire, Sistrom \& Stanier (1957) demonstrated that there is an inverse relation between the concentration of bacteriochlorophyll and carotenoid pigments in cells of Rhodopseudomonas spheroides and the light intensity in which the cells have been grown. When a culture is transferred from dim to bright light, synthesis of the photopigments stops, while cell growth continues; thus the specific pigment contents ( $\mu \mathrm{g}$. pigment/100 $\mu \mathrm{g}$. cell protein) decrease to the levels characteristic of the higher light intensity. On the other hand, when a culture is transferred from bright to dim light, the growth rate, as measured by increase in turbidity, is markedly reduced, while the photopigments continue to be synthesized. Thus, the specific pigment contents increase to the levels characteristic of the lower intensity. As these levels are approached, cell growth begins again and eventually both the turbidity of the culture and the photopigments are increasing at the same rate (Cohen-Bazire et al. 1957).

This behaviour is an example of regulation of cellular metabolism by 'feed-back' control. In order to gain a better understanding of the mechanism of this regulation, it was necessary to undertake a more detailed analysis of the kinetics of photopigment synthesis than had been attempted by Cohen-Bazire and co-workers. This paper reports the results of experiments on the differential rate of photopigment synthesis relative to the rate of synthesis of cell protein. These results provide a basis for a more complete description of the control of pigment synthesis in Rhodopseudomonas spheroides than was hitherto possible.

\section{METHODS}

Rhodopseudomonas spheroides strain Ga was used throughout. Medium A of Sistrom (1960) was used, with succinic acid as carbon source, and supplemented with L-glutamic acid (100 $\mu \mathrm{g} . / \mathrm{ml}$.) and L-aspartic acid (40 $\mu \mathrm{g} . / \mathrm{ml}$.$) ; this is medium$ 
AG Su. The conditions of growth and the general methodology have been described in the preceding paper (Sistrom, 1962). The details of the procedures used in the several experiments are described separately.

\section{RESULTS}

\section{The effect of self-shading}

Before attempting measurements of the differential rates of photopigment synthesis, it was necessary to assess the effect of self-shading in cultures of Rhodopseudomonas spheroides, since it is clear that pigment synthesis is influenced not by the amount of light incident on a culture but by the light absorbed by it.

Preliminary experiments showed that under the conditions employed, self-shading is not appreciable unless the bacteriochlorophyll concentration is greater than 5-6 $\mu \mathrm{g} . / \mathrm{ml}$. At pigment concentrations greater than this the amount of light absorbed is no longer proportional to the pigment concentration. Consequently, in a growing culture, the specific pigment content will be constant only if the bacteriochlorophyll concentration is less than about $5 \mu \mathrm{g} . / \mathrm{ml}$. In these experiments the effect of selfshading has been circumvented by keeping the bacteriochlorophyll concentration as low as possible.

Cohen-Bazire et al. (1957) reported the growth rates and specific pigment contents of cultures grown in different light intensities. In these experiments no account was taken of self-shading; it was of interest to repeat these measurements under more carefully controlled conditions. To obviate the effect of self-shading, the experiments were conducted so that at each light intensity employed the bacteriochlorophyll concentration increased from about 0.5 1.5 $\mu \mathrm{g} . / \mathrm{ml}$. during the time analyses were made. The specific bacteriochlorophyll content and the growth at a bacteriochlorophyll concentration of $1.0 \mu \mathrm{g} . / \mathrm{ml}$. were calculated by interpolation. The results are incorporated in Fig. 1. Two points are of interest here. In the first place, the maximum specific growth rate is about 0.75 doublings per $100 \mathrm{~min}$. which is equivalent to a generation time of a little over $2 \mathrm{hr}$. This growth rate is considerably greater than the maximum reported by Cohen-Bazire and co-workers. The second point is that any decrease in the light intensity causes not only an increase in pigment content but also a decrease in growth rate. In other words, the increased pigment content is never equivalent to the decrease in light intensity. This point will be considered further in the discussion.

\section{Chlorophyll synthesis and protein turnover}

The experiments of Cohen-Bazire et al. showed that photo-pigments are apparently synthesized preferentially when a culture of Rhodopseudomonas spheroides, grown in bright light, is transferred to dim light. This recalls the synthesis of $\beta$-galactosidase during adaptation of Escherichia coli to lactose (Rickenberg \& Lester, 1955). Mandelstam (1960) has shown that in this case preferential synthesis is not the result of an increased differential rate of enzyme synthesis during adaptation, but that the extent of protein synthesis is masked by a simultaneous breakdown of pre-existing protein. Protein turnover appears to be of general occurrence in micro-organisms whenever the cells are starved for nitrogen or carbon. It was of interest to see if protein turnover occurs during the period of rapid bacteriochlorophyll synthesis after a culture of $\boldsymbol{R}$. spheroides is transferred to dim light, and 
while the cells are presumably starved for energy. The extent of turnover was estimated by comparing the amount of phenylalanine incorporated into protein with the amount released from protein under identical conditions (Mandelstam, 1958).

Three hundred ml. of medium ASu (without glutamic or aspartic acid) containing uniformly labelled ${ }^{14} \mathrm{C}$-L-phenylalanine (25 $\left.\mu \mathrm{g} . / \mathrm{ml} . ; 42 \mathrm{c.p} . \mathrm{m} . / \mu \mathrm{g}.\right)$ was inoculated with Rhodopseudomonas spheroides. The culture was grown in a light intensity of $12,000 \mathrm{ft} . c$. for at least five generations to assure complete labelling of the protein. The culture was centrifuged and resuspended in the same volume of

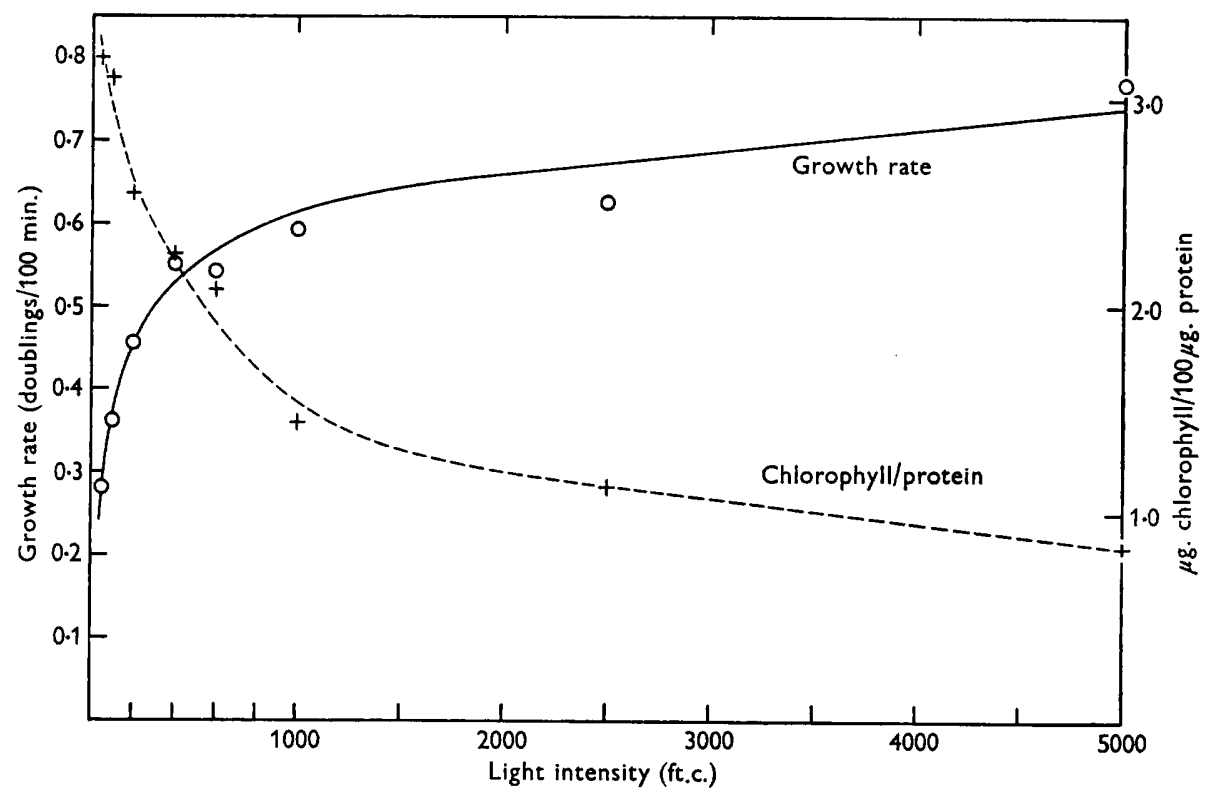

Fig. 1. The specific growth rate constant and the specific bacteriochlorophyll content of Rhodopseudomonas spheroides at various light intensities. The values in each case are for a culture with $1 \mu \mathrm{g}$. of bacteriochlorophyll $/ \mathrm{ml}$. Medium AG Su; aeration mixture $5 \%$ $(\mathrm{v} / \mathrm{v})$ in $\mathrm{N}_{2}$.

medium containing non-radioactive L-phenylalanine $(25 \mu \mathrm{g} . / \mathrm{ml}$.$) , and allowed to$ grow under the original conditions for $1 \mathrm{hr}$. This served to reduce radioactivity of the phenylalanine pool. The culture was centrifuged, washed once and resuspended in $300 \mathrm{ml}$. of medium ASu with $100 \mu \mathrm{g}$. L-phenylalanine $/ \mathrm{ml}$., incubated anaerobically $\left(5 \%(\mathrm{v} / \mathrm{v}) \mathrm{CO}_{2}\right.$ in $\left.\mathrm{N}_{2}\right)$ in a light intensity of $80 \mathrm{ft} . c$. Protein and bacteriochlorophyll were determined periodically. At intervals, $16 \mathrm{ml}$. samples were taken to measure the radioactivity in protein and in the medium. $1.6 \mathrm{ml}$. of cold $50 \%$ trichloroacetic acid was added to each sample, after $20 \mathrm{~min}$. in the cold the suspension was centrifuged. The pellet was washed once with cold $5 \%$ TCA containing L-phenylalanine (1 mg./ml.) and resuspended in $4 \mathrm{ml}$. of water containing $200 \mu \mathrm{g}$. Duponal C per $\mathrm{ml}$. (obtained from E. I. Dupont Company, Wilmington, Delaware). The radioactivity of duplicate $1 \mathrm{ml}$. samples was measured. The cold TCA supernatant was put on a Dowex 50-W column $(1.5 \times 4.0 \mathrm{~cm}$. $)$; the resin was washed with $50 \mathrm{ml}$. of water and eluted with $1.5 \mathrm{M}-\mathrm{NH}_{4} \mathrm{OH}$. The first $10 \mathrm{ml}$. of eluate was discarded, the next $\mathbf{5 0}$ ml. was collected in a beaker and evaporated to dryness. The residue was dissolved 
in a little water and quantitatively transferred to planchets and the radioactivity determined. In preliminary experiments this method gave about $90 \%$ recovery of radioactive phenylalanine.

A non-radioactive culture was prepared in a similar fashion. It was suspended in $300 \mathrm{ml}$. of medium $\mathrm{ASu}$ containing radioactive phenylalanine (10 $\mu \mathrm{g} . / \mathrm{ml}$; 157 c.p.m. $/ \mu \mathrm{g}$.$) , and incubated anaerobically in 80 \mathrm{ft} . c$. of light. Protein and bacteriochlorophyll were determined periodically. At intervals, samples were taken and treated with $5 \%$ TCA in the cold for 20 min. The suspension was centrifuged and the supernatant discarded. The pellet was resuspended in boiling $5 \%$ TCA containing $1 \mathrm{mg}$. L-phenylalanine per $\mathrm{ml}$. and centrifuged. The pellet was dissolved in $2 \mathrm{ml}$. of $2 \mathrm{M}-\mathrm{NaOH}$ and reprecipitated by the addition of $2 \mathrm{ml}$. of $20 \%$ TCA. This precipitate was washed twice with $5 \mathrm{ml}$. portions of acetone and finally dissolved in $1 \cdot 4 \mathrm{ml}$. of $\mathrm{M}-\mathrm{NH}_{4} \mathrm{OH}$. Duplicate $1 \mathrm{ml}$. samples were counted. Preliminary experiments showed that this treatment removed only a negligible fraction of the radioactivity of the cold TCA precipitate.

Figure 2 shows the fraction of the initial phenylalanine released or incorporated during the time bacteriochlorophyll synthesis is proceeding rapidly. The amount of phenylalanine released amounted to less than $10 \%$ of the amount incorporated; it is concluded that there is virtually no protein turnover during this time. This finding is substantiated by the experiment described in the previous paper which showed that there is no detectable synthesis of bacteriochlorophyll in cells deprived of an essential amino acid.

\section{The differential rate of pigment synthesis}

Cohen-Bazire and co-workers presented an hypothesis to explain the control of photopigment synthesis they had observed in the non-sulphur purple bacteria. According to this hypothesis, the differential rate of pigment synthesis at a given light intensity should be inversely proportional to the specific pigment content of the cells, if the pigment content is less than the steady-state value. The experiments described below were designed to test this prediction. They provide a detailed description of the kinetics of photopigment synthesis, especially of the differential rate of pigment synthesis relative to protein synthesis.

The differential rate in depigmented cells. In these experiments the effects on the differential rate of the light intensity and of the initial specific bacteriochlorophyll content were studied. The general procedure was to expose a culture of Rhodopseudomonas spheroides to two light intensities, 80 and $500 \mathrm{ft.c.}$; bacteriochlorophyll, carotenoid pigments and protein and the uptake of ${ }^{14} \mathrm{C}$-phenylalanine into protein were determined at intervals. In order to reduce the effect of self-shading, these experiments were usually terminated before the cultures had become fully pigmented.

The details and results of a typical experiment are given in Fig. 3. In this experiment the culture was first grown in a light intensity of $12,000 \mathrm{ft.c}$. and then exposed to $80 \mathrm{ft} . c$. during the experiment. The amount of protein synthesized did not greatly exceed the limits of error of the Folin-Lowry method (Lowry, Rosebrough, Farn \& Randall, 1951). The turbidity of the culture actually decreased during the first $200 \mathrm{~min}$. or so. Clearly, the differential rate relative to either turbidity or protein 
cannot be determined accurately. It is for this reason that the uptake of phenylalanine has been used as a measure of cell growth.

In Fig. 4 the increase in bacteriochlorophyll has been plotted relative to the increase in phenylalanine; the slope of this curve gives the differential rate directly. It can be seen that except for a small lag the differential rate is constant throughout the experiment; this constancy is maintained in the face of a nearly threefold increase in specific bacteriochlorophyll content. The final bacteriochlorophyll concentration was $5 \mu \mathrm{g} . / \mathrm{ml}$.; self-shading can accordingly be neglected.

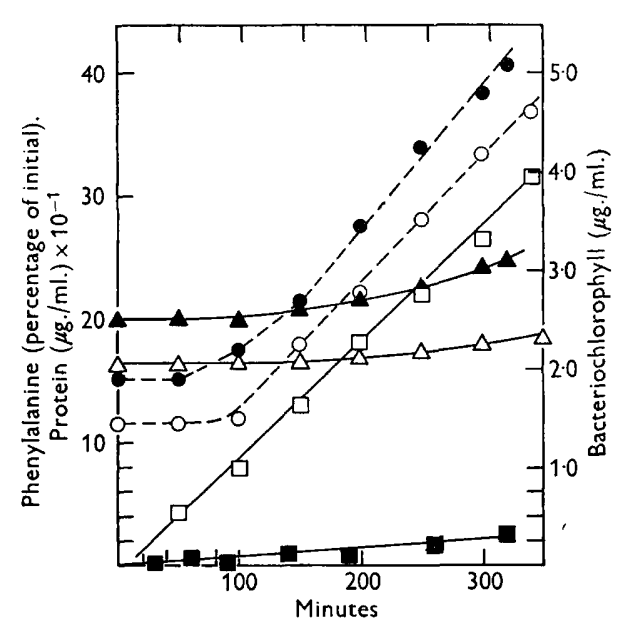

Fig. 2

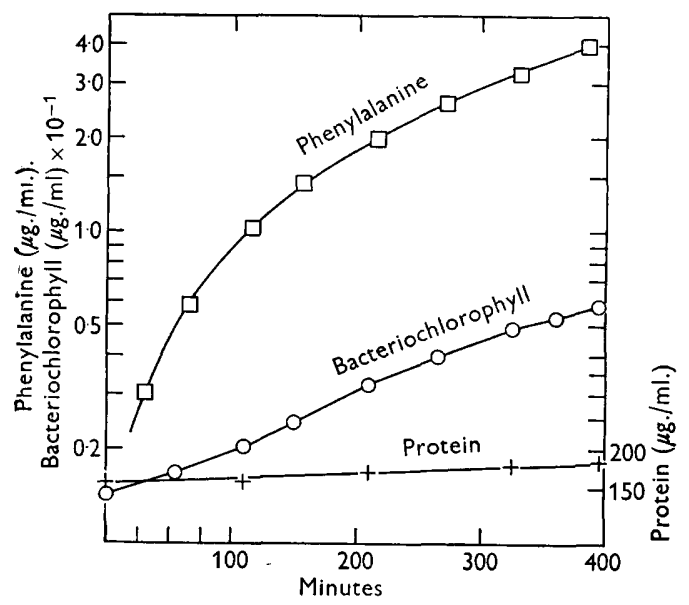

Fig. 3

Fig. 2. Uptake and release of ${ }^{14} \mathrm{C}$-phenylalanine during preferential synthesis of bacteriochlorophyll. See text for experimental details. Results with prelabelled culture shown by filled points, those with initially unlabelled culture by open points. $\square$, Phenylalanine (\% initial); O, bacteriochlorophyll ( $\mu \mathrm{g} . / \mathrm{ml}.) ; \Delta$, protein ( $\mu \mathrm{g} . / \mathrm{ml}$.$) .$

Fig. 3. Bacteriochlorophyll synthesis and uptake of ${ }^{14} \mathrm{C}$-phenylalanine by a depigmented culture of Rhodopseudomonas spheroides. The culture was grown in a light intensity of c. 12,000 ft.c. in medium AG Su with $25 \mu \mathrm{g}$. L-phenylalanine $/ \mathrm{ml}$. It was suspended in AG Su and aerated with $5 \%(v / v) \mathrm{CO}_{2}$ in $\mathrm{N}_{2}$ for $10 \mathrm{~min}$. in the dark. At zero time ${ }^{14} \mathrm{C}-\mathrm{L}-$ phenylalanine (60 c.p.m. $/ \mu \mathrm{g}$.) was added to a final concentration of $20 \mu \mathrm{g} . / \mathrm{ml}$. and the culture illuminated with $80 \mathrm{ft}$.c. The radioactivity of the material precipitated by $5 \%$ TCA was determined. $\square$, L-phenylalanine ( $\mu \mathrm{g} . / \mathrm{ml}$.$) ; \bigcirc$, bacteriochlorophyll ; + , protein.

This result was unexpected and not in accord with the hypothesis of CohenBazire et al. which predicts that the differential rate should decrease as the specific pigment content increases. This result became even more difficult to understand when the experiment was repeated with cultures of different initial specific bacteriochlorophyll contents. The results of several such experiments are collected in Table 1. The culture grown in $\mathbf{5 0 0} \mathrm{ft} . c$. was fully pigmented at the start of the experiment; and that grown in $1000 \mathrm{ft} . c$. became so during the experiment. The differential rate in these two cultures is the same as that for fully pigmented cells under these conditions. Inspection of this table shows that the differential rate increases with decreasing initial specific bacteriochlorophyll content and has a maximum of about $1 \cdot 4 \mu \mathrm{g}$. bacteriochlorophyll $/ \mu \mathrm{g}$. phenylalanine, which is about 3 times the rate in fully pigmented cells. 
In Table 2 the differential rates in cultures exposed to $500 \mathrm{ft} . c$. are shown. These results are subject to greater error than those of Table 1, since the cultures become fully pigmented quickly and since the bacteriochlorophyll concentration soon becomes high enough to cause self-shading. Nevertheless, it seems clear that here too the differential rate is higher in cultures with low specific pigment contents and furthermore that the maximum value of 0.8 is less than the maximum differential rate found in cultures exposed to $80 \mathrm{ft} . c$.

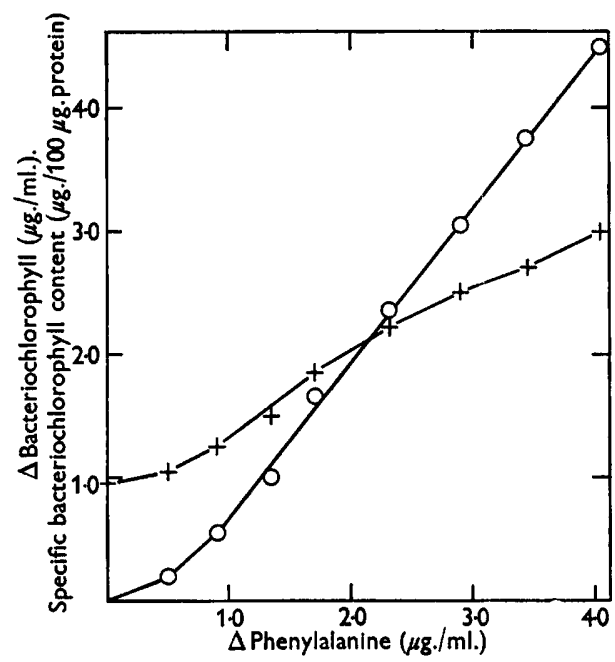

Fig. 4

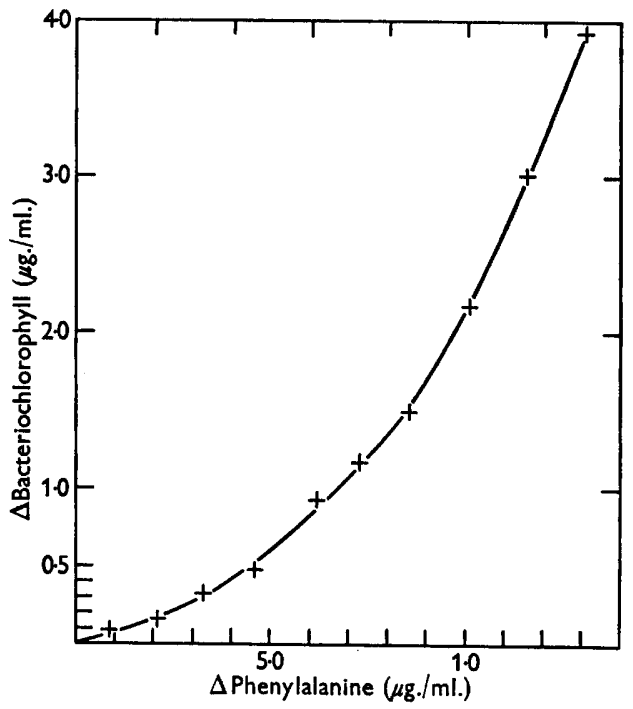

Fig. 5

Fig. 4. The differential rate of bacteriochlorophyll synthesis. The results shown in Fig. 3 have been replotted. $O$, Increase in bacteriochlorophyll $(\mu \mathrm{g} . / \mathrm{ml}) ;$.+ , specific bacteriochlorophyll content $(\mu \mathrm{g} . / 100 \mu \mathrm{g}$. of protein). Each is plotted relative to the increase in TCA-insoluble phenylalanine $(\mu \mathrm{g}$. $/ \mathrm{ml}$.). The differential rate is $1.2 \mu \mathrm{g}$. bacteriochlorophyll $/$ $\mu \mathrm{g}$. phenylalanine.

Fig. 5. The differential rate of bacteriochlorophyll synthesis following repression by high light intensity. A culture of Rhodopseudomonas spheroides was grown in a light intensity of $80 \mathrm{ft} . c$. ; at the start of the experiment the light intensity was increased to $500 \mathrm{ft} . c$. and ${ }^{14} \mathrm{C}$-L-phenylalanine (175 c.p.rn. $/ \mu \mathrm{g}$.) added to a concentration of $25 \mu \mathrm{g} . / \mathrm{ml}$. Bacteriochlorophyll synthesis did not begin until $250 \mathrm{~min}$. In the figure the increase in bacteriochlorophyll has been plotted against the increase in TCA-insoluble phenylalanine.

These results are paradoxical. On the one hand, the differential rate in any given culture is independent of specific pigment content; but, on the other hand, the differential rate depends on both the initial pigment content of the culture and on the light intensity to which it is exposed. A possible resolution of this paradox is offered in the discussion.

It is clear that the differential rate in an initially depigmented culture must eventually decrease and become equal to that in a fully pigmented culture. The experiments just described suggest that the decrease does not begin until the culture has become very nearly fully pigmented. This was confirmed by the following experiment. A culture, grown in 10,000 ft.c. of light, was exposed to $100 \mathrm{ft}$.c. At intervals the culture was diluted with fresh medium so that the bacteriochlorophyll 
concentration was maintained between 1.0 and $1.5 \mu \mathrm{g} . / \mathrm{ml}$. The effect of selfshading was thereby kept to a minimum. The differential rate remained constant at a value of about $1.0 \mu \mathrm{g}$. bacteriochlorophyll $/ \mu \mathrm{g}$. amino acid incorporated until the specific pigment content was within $10-15 \%$ of the value finally attained. The

Table 1. Differential rate of bacteriochlorophyll synthesis in Rhodopseudomonas spheroides exposed to light intensity of 80 ft.c.

\begin{tabular}{|c|c|c|c|c|c|}
\hline \multirow{3}{*}{$\begin{array}{l}\text { Light } \\
\text { intensity } \\
\text { during } \\
\text { growth }\end{array}$} & \multicolumn{4}{|c|}{ Bacteriochlorophyll } & \multirow{3}{*}{$\begin{array}{c}\text { Differential } \\
\text { rate* }\end{array}$} \\
\hline & \multicolumn{2}{|c|}{$\mu \mathrm{g} . / \mathrm{ml}$} & \multicolumn{2}{|c|}{$\begin{array}{c}\mu \mathrm{g} \cdot / 100 \mu \mathrm{g} . \\
\text { protein }\end{array}$} & \\
\hline & Initial & Final & Initial & Final & \\
\hline 12,000 & $1 \cdot 4$ & $5 \cdot 8$ & 0.9 & $\mathbf{3} \cdot \mathbf{2}$ & $\mathbf{1 \cdot 2 5}$ \\
\hline 12,000 & $\mathbf{1} \cdot \mathbf{4}$ & $6 \cdot 0$ & 0.85 & $\mathbf{3} \cdot \mathbf{1}$ & $1 \cdot 35$ \\
\hline 10,000 & $\mathbf{2 \cdot 3}$ & $6 \cdot 5$ & $\mathbf{1} \cdot \mathbf{3}$ & $\mathbf{3} \cdot \mathbf{1}$ & $1 \cdot 1$ \\
\hline 6,000 & $\mathbf{2 \cdot 3}$ & $6 \cdot 8$ & $1 \cdot 6$ & $3 \cdot 7$ & 0.9 \\
\hline 3,000 & $\mathbf{2 \cdot 3}$ & 4.5 & $2 \cdot 1$ & $3 \cdot 7$ & 0.75 \\
\hline 1,000 & $2 \cdot 15$ & $\mathbf{3} \cdot \mathbf{3}$ & $\mathbf{3} \cdot \mathbf{1}$ & $3 \cdot 5$ & $0 \cdot 4$ \\
\hline $500 \dagger$ & $1 \cdot 4$ & $2 \cdot 05$ & $5 \cdot 8$ & $\mathbf{3 \cdot 2 5}$ & 0.45 \\
\hline Aerobic $¥$ & $0 \cdot 65$ & $3 \cdot 0$ & $0 \cdot 2$ & $1 \cdot 0$ & $1 \cdot 4$ \\
\hline
\end{tabular}

* $\mu \mathrm{g}$. bacteriochlorophyll $/ \mu \mathrm{g}$. phenylalanine incorporated.

$\dagger$ The inoculum for this experiment was diluted sevenfold, the reduction in self-shading occasioned by this more than compensated for the reduction in the light intensity; accordingly, pigment synthesis was inhibited for about $200 \mathrm{~min}$. The differential rate is given for the period after pigment synthesis recommenced.

$\ddagger$ The pigment content of a photosynthetically grown culture was reduced by a period of aerobic growth (see Sistrom, 1962).

Table 2. Differential rate of bacteriochlorophyll synthesis in Rhodopseudomonas spheroides exposed to a light intensity of 500 ft.c.

\begin{tabular}{|c|c|c|c|c|c|}
\hline \multirow{3}{*}{$\begin{array}{l}\text { Light } \\
\text { intensity } \\
\text { during } \\
\text { growth }\end{array}$} & \multicolumn{4}{|c|}{ Bacteriochlorophyll } & \multirow{3}{*}{$\begin{array}{c}\text { Differential } \\
\text { rate* }\end{array}$} \\
\hline & \multicolumn{2}{|c|}{$\mu \mathrm{g} . / \mathrm{ml}$} & \multicolumn{2}{|c|}{$\begin{array}{c}\mu \mathrm{g} \cdot / 100 \mu \mathrm{g} . \\
\text { protein }\end{array}$} & \\
\hline & Initial & Final & Initial & Final & \\
\hline 12,000 & $1 \cdot 4$ & $6 \cdot 0$ & $0 \cdot 85$ & $\mathbf{3 \cdot 0}$ & $0 \cdot 80$ \\
\hline 10,000 & $2 \cdot 3$ & $6 \cdot 8$ & $1 \cdot 3$ & $2 \cdot 6$ & $0 \cdot 80$ \\
\hline 6,000 & $\mathbf{2} \cdot \mathbf{3}$ & $6 \cdot 2$ & $1 \cdot 6$ & $2 \cdot 9$ & 0.75 \\
\hline 3,000 & $2 \cdot 3$ & $4 \cdot 75$ & $\mathbf{2} \cdot \mathbf{1}$ & $2 \cdot 7$ & $0 \cdot 60$ \\
\hline $1,000 \dagger$ & $2 \cdot 15$ & $2 \cdot 4$ & $\mathbf{3} \cdot 15$ & $2 \cdot 4$ & $\mathbf{0 \bullet 3 0}$ \\
\hline Aerobic $\ddagger$ & 0.65 & $4 \cdot 0$ & $0 \cdot 2$ & $1 \cdot 2$ & 0.85 \\
\hline
\end{tabular}

* $\mu \mathrm{g}$. bacteriochlorophyll/ $\mu \mathrm{g}$. phenylalanine incorporated.

$\dagger$ The inoculum for this experiment was diluted; the reduction in self-shading occasioned by this more than compensated for the decrease in light intensity and pigment synthesis was inhibited. The differential rate given is for the period after pigment synthesis recommenced.

$\ddagger$ See note $\ddagger$ in Table 1 .

differential rate then declined to a value of $0 \cdot 6$ in the fully pigmented culture. In this experiment ${ }^{35} \mathrm{~S}$-methionine was employed in place of ${ }^{14} \mathrm{C}$-phenylalanine; this was done to eliminate the possibility that the kinetics of phenylalanine incorporation were in any way responsible for the results. 
The differential rate after recommencement of pigment synthesis. The experiments which have just been described were carried out with depigmented cultures, in which the specific pigment content was increasing to the level found in fully pigmented cultures. It was of interest to examine the relation between specific bacteriochlorophyll content and the differential rate, in cultures which initially have an excess of photopigments. This can be done by transferring a culture grown in dim light to bright light. Under these conditions pigment synthesis is repressed while

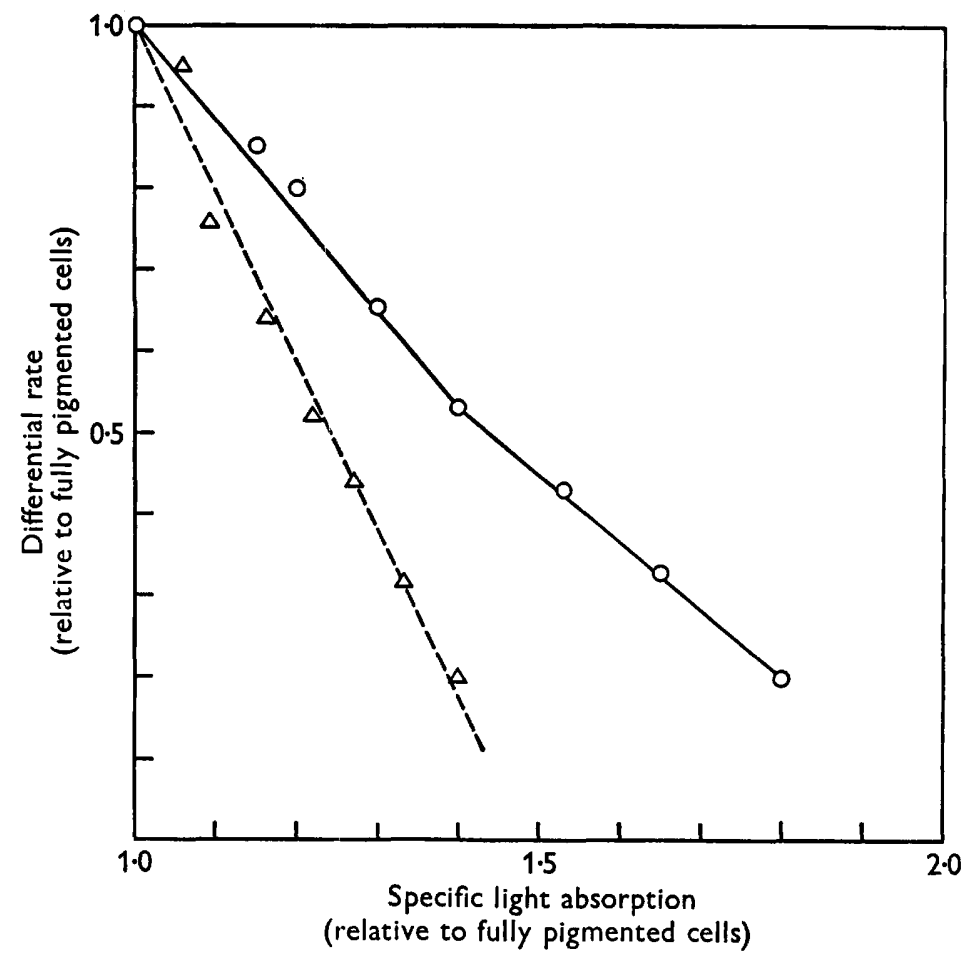

Fig. 6. Differential rate of bacteriochlorophyll synthesis and specific pigment content. Data from two experiments similar to the one deseribed in Fig. 5 have been recalculated. Both the differential rate and the specific bacteriochlorophyll content are expressed relative to the values they finally attain.

growth continues. The specific pigment content therefore decreases until it reaches the value characteristic for that light intensity, at which time pigment synthesis recommences. In these experiments the differential rate was measured during the period just after the recommencement of bacteriochlorophyll synthesis. The results of a typical experiment are shown in Fig. 5. In this experiment the culture was grown in a light intensity of $80 \mathrm{ft.c}$. and then exposed to one of $500 \mathrm{ft} . c$. The figure shows the increase of bacteriochlorophyll plotted against the increase of phenylalanine incorporated. It is clear that the differential rate is constantly increasing. During this same time the specific pigment content is still falling, since the differential rate is still less than that for fully pigmented cells. The relation between the differential rate and the specific bacteriochlorophyll content is linear as shown in Fig. 6. 


\section{DISCUSSION}

The experiments reported here confirm the finding of preferential synthesis of the photopigments in the non-sulphur purple bacteria originally reported by CohenBazire et al. (1957). These workers measured growth by turbidity only and the significance of the preferential synthesis they observed was therefore uncertain, since this method would not have detected turnover of protein or other cell components. In the present experiments the differential rate of pigment synthesis was measured relative to the uptake of amino acids into protein rather than to net protein synthesis; protein turnover would not affect these results. In addition, it has been shown directly that there is no turnover of protein during the preferential synthesis of bacteriochlorophyll.

There are two possible interpretations of this preferential synthesis. The first is that all components of the photosynthetic apparatus are synthesized preferentially with respect to the rest of the cell. The second is that the specific pigment content of the photosynthetic apparatus itself increases. At the present time neither interpretation can be ruled out.

These experiments have revealed several facts about the control of pigment synthesis in Rhodopseudomonas spheroides which must be taken into account by any hypothesis about the mechanism of this control. (1) Both the specific pigment content and the growth rate change continuously with light intensity; the control of pigment synthesis does not operate so as to keep the growth rate constant. (2) The differential rate of pigment synthesis can remain constant while the specific pigment content is increasing. In other words, under some conditions the differential rate is not proportional to the amount of pigment. (3) When pigment synthesis resumes after an increase in light intensity the differential rate is inversely proportional to specific pigment content.

Only the last of these observations is in accord with the hypothesis originally proposed by Cohen-Bazire et al. This said that the control of pigment synthesis operated in such a way as to maintain the concentration of some substance constant and that changes in the concentration of this 'regulator', induced by changes in light intensity, were transient. The observations reported here are easier to interpret on the basis of a model in which the concentration of the 'regulator' does not tend to remain constant and in which a change in the light intensity induces a permanent change in the 'regulator' concentration.

The results shown in Table 1 and 2 show that although the differential rate is independent of specific pigment content in any one culture it does depend upon the initial pigment content when different cultures are compared. The results depicted in Fig. 1 show that it is impossible to obtain cultures with different specific pigment contents which have had the same specific growth rates. It is possible, therefore, that the apparent dependence of the differential rate on initial pigment content is really a dependence on the previous growth rate of the culture. This possibility can be checked by using cultures grown at a fixed rate in a chemostat in different light intensities. Such experiments are in progress.

This work was supported in part by a grant from the National Science Foundation (G-14983) and in part by a grant from the National Council to Combat Blindness (G-232). 


\section{REFERENCES}

Cohen-Bazire, G., Sistrom, W. R. \& Stanier, R. Y. (1957). Kinetic studies of pigment synthesis by non-purple sulfur bacteria. J. cell. comp. Physiol. 49, 25.

Lowry, O. H., Rosebrough, N. J., Farn, A. L. \& Randall, R. J. (1951). Protein measurement with Folin phenol reagent. J. biol. Chem. 193, 265.

MANDELSTAM, J. (1958). Turnover of protein in growing and non-growing populations of Escherichia coli. Biochem. J. 69, 110.

Mandelstam, J. (1960). The intracellular turnover of protein and nucleic acids and its role in biochemical differentiation. Bact. Rev. 24, 289.

Rickenberg, H. V. \& Lester, G. (1955). The preferential synthesis of $\beta$-galactosidase in Escherichia coli. J. gen. Microbiol. 13, 279.

Sistrom, W. R. (1960). A requirement for sodium in the growth of Rhodopseudomonas spheroides. J. gen. Microbiol. 22, 778.

Sistrom, W. R. (1962). Observations on the relationship between the formation of photopigments and the synthesis of protein in Rhodopseudomonas spheroides. J. gen. Microbiol. 28, 599. 